\title{
Development of a Turbo Electric Distribution System for Remotely Piloted Aircraft Systems
}

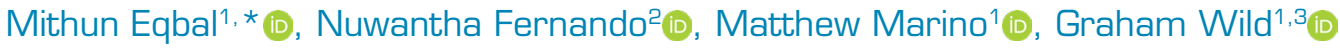

1.Royal Melbourne Institute of Technology University - School of Aerospace Engineering and Aviation - Melbourne/Victoria - Australia. 2.Royal Melbourne Institute of Technology University - School of Electrical and Biomedical Engineering - Melbourne/Victoria Australia. 3.University of New South Wales Canberra - School of Engineering and Information Technology - Canberra - Australia

*Corresponding author: mithun.eqbal@rmit.edu.au

\begin{abstract}
Turboelectric distributed propulsion systems are paving the way for more electric aircraft systems (TeDP). This type of system provides a solution for some of the drawbacks of current low-energy-density batteries, which limit the ability of long-endurance electric aircraft. However, turboelectric propulsion requires the use of advanced turboelectric motors, superconductive materials and cryogenic cooling technologies, which are still under development and may be in production in the near future. This paper investigates a turboelectric propulsion system that can be considered an initial step in the production of TeDP in a remotely piloted aircraft system with the use of existing technology. This is achieved by replacing the gear and the starter motor of a turboprop with a high-speed permanent magnet electric machine to generate electrical power and propelling the aircraft through a distributed electric propulsion system. In this theoretical study, an augmentation to Breguet's range and endurance equation is developed. This study confirmed that the new system is $31 \%$ lighter than the turboprop engine. Then the effect of the weight savings is used in the distributed electric propulsion (DEP) aerodynamic studies and found that there is a drastic increase in the range for a TeDP developed with the high-speed machine.
\end{abstract}

Keywords: Turboprop gear system; Distributed propulsion systems; High-speed machines.

\section{INTRODUCTION}

The development of efficient propulsion systems for aircraft is vital not only in response to fuel costs and supply, but also to address environmental concerns. There are various forms of internal combustion (IC), electric and hybrid propulsion systems, which are currently being developed to improve overall performance. Pure IC engines convert the chemical energy stored in fuel to mechanical energy via combustion, while the electric engine converts the chemical energy stored in the battery to mechanical energy. The former delivers higher range and endurance, while the latter has higher propulsive efficiency and offers design flexibility. A hybrid system uses the benefit of both to offer an advanced propulsion system (Eqbal et al. 2018).

Received: May 082020 | Accepted: Jan. 052021

Peer Review History: Double Blind Peer Review.

Section Editor: T. John Tharakan

This is an open access article distributed under the terms of the Creative Commons license. 
Among the advanced hybrid propulsion technologies, one of the most promising concepts is the turboelectric distributed propulsion system (TeDP). This system has been at the forefront of new propulsion concepts (Nalianda and Singh 2014) and part of the National Aeronautics and Space Administration (NASA) subsonic fixed wing (SFW) project to reduce the aircraft fuel burn, emission and noise (Kim et al. 2018). By definition, TeDP is a series hybrid propulsion system where a gas turbine engine is used to power a directly coupled electric generator to produce electric power. This electrical power is transferred to small electric motors called propulsors (Bowman et al. 2018). This type of system is commonly used in ships and trains where a diesel engine is used to power electric motors for locomotive motion (Hayes and Goodarzi 2018). The method of using multiple electric motors to propel the aircraft, rather than a single motor, is known as distributed electric propulsion (DEP) (Nalianda and Singh 2014).

The main advantage of TeDP is that the core gas turbine is isolated from the propulsors. This, in turn, allows the gas turbine and the electric motor to run in its optimum operating condition and is similar to a series hybrid configuration (Eqbal et al. 2018). Other advantages of TeDP include reduction in weight of aircraft and wing structure (Ko et al. 2003), and reduction in sound levels (Thomas 2003; Hill et al. 2004; Diedrich et al. 2006). Furthermore, a significant advantage is a reduction in operational costs due to fuel, as the system is theorized to be working at higher efficiencies across various stages throughout the mission. Further improvements to propulsive efficiency have been investigated, such as a distributed propulsion system acting as a boundary layer injection system to add aerodynamic benefits into the overall aircraft design (Teperin et al. 2017). Such concepts allow for integration flexibility for use in various aircraft configurations, such as tube and wing (T\&W) (Felder et al. 2011; Lian and Wu 2018), hybrid wing body (HWB), blended wing body (BWB) and placing the propulsions strategically in the specific sections of the aircraft, that can reduce the drag and increase lift.

Boundary layer injection (BLI) serves as the base for all the advantages exhibited by DEP. The fundamental principle of BLI propulsion is that a propulsor ingests and reaccelerates the airframe boundary layer, which reduces the wake deformation downstream. It then adds kinetic energy for the same net force, which decreases the power to be added to the flow by propulsor (Teperin et al. 2017). In other words, the propulsion is directed to fill in the wing wake reducing boundary layer and pressure drag while increasing the propulsive efficiency (Moore and Fredericks 2014; Moore and Ning 2018). Theoretical studies conducted by Smith Junior (1993) have shown that there is an increase in propulsive efficiency of $127 \%$.

Similarly, Ameyugo et al. (2006) has shown, in a numerical investigation, the power savings of $12.2 \%$ and the propulsive efficiency of the BLI propulsor is $117.3 \%$ compared to the free stream propulsor of $80.9 \%$. In a remotely piloted aircraft systems (RPAS), Teperin et al. (2017) showed the power saving coefficient of $21 \%$ when a propeller is placed behind the fuselage compared to the forward position and drag coefficient is $28.5 \%$ less. Similarly, Rao et al. (2017) has shown a reduction in shaft power in case of wake injection by $10 \%$ and BLI by $18 \%$. Two independent experiments at NASA achieved a propulsive efficiency of $103 \%$ (Goldschmied 1986), while others found that 50\% power could be saved using BLI and counter-rotating propellers in an experimental aircraft. Additionally, Alba et al. (2017) has shown the total drag reduction of over $30 \%$ by optimizing the wing chord and twist distribution behind a given propeller.

Distributed electric propulsion also has positive advantages during takeoff when the aircraft requires more power. In a conceptual design, the study found that a wing with propellers across the entire span at the optimal diameter for the load (8 propellers for a $300 \mathrm{~km}$ range constraint) can reduce the takeoff distance by over $80 \%$ when compared to the optimal 2 propeller case using the same models (Moore and Ning 2018). There is over a 100\% increase in the wing lift coefficient, which leads to a $36 \%$ reduction in lift-off speed. The concept also is capable of producing 2.9 times more thrust during takeoff with only an $11 \%$ increase in total aircraft mass. Moreover, NASA is developing a full electric DEP aircraft named X-57 Maxwell and has shown that the DEP can provide a positive change to the lift during takeoff and landing (Borer et al. 2019).

Distributed electric propulsion comes with technical challenges, such as finding the right balance between the electric motor and the propeller. The higher the speed of propulsor motor, the lower the overall structural weight. Nevertheless, this can create a high propeller tip speed and approaching Mach 1 creates shockwaves and has a detrimental to not only the propulsive efficiency but also impacts propeller maintenance and lifecycle (Hanson and Fink 1979; Hitchens 2015). The turbo-electric engines in development need high electrical efficiencies, capabilities associated with superconductivity to be viable (Armstrong 2015). 
Another issue is that, with the present technology, it is not possible to create a TeDP system that is light enough to be efficient. All these drawbacks open the possibility of a direct-run high speed machine to generate power, where it replaces the large gear systems in a turboprop or a turboshaft engine.

A number of high-speed electrical machine options exist for the use as a turbine coupled power generator for DEP. Over the past two decades, electrical machines have been developed for high-speed operations with military and civil aeroengine integration, high-speed turbochargers, air compressors and microturbines, in addition to high-speed machine tools. The technology can also be scaled down and translated for the use in turbo-electric power generation in RPASs. The candidate electrical machine options are the switched reluctance machine, flux switching machine, induction machine and the permanent magnet machine.

The switched reluctance machine (Fernando and Barnes 2013; Fernando 2014; Yu et al. 2018) and the flux switching machine (Nasr et al. 2017; Selema et al. 2018) have been proposed for more-electric aircraft power generation systems. High speed induction machines (Pyrhonen et al. 2009) have been developed for high-speed waste heat recovery systems. In contrast, more researches have been conducted on high-speed permanent magnet machines (Fernando et al. 2011; Fernando et al. 2016; Fernando et al. 2018; Song et al. 2019; Varyukhin et al. 2019; Wang et al. 2019; Xu et al. 2019). The permanent magnet machine offers higher power density compared with the other forms of machines due to the high air-gap flux density. As a result, the permanent magnet machine can be considered as the most suitable option for DEP in RPAS. Other machines, such as the switched reluctance machine and the induction machine, offer the advantage of operability in high temperatures, such as in applications where the machine is directly integrated within the turbine spool. However, when the machine can be placed externally and coupled with the turbine spool with sufficient cooling such as in RPAS, the permanent magnet machine option tends to be optimal due to a comparatively lower weight.

High power to weight ratio of high-speed machines (Ma et al. 2015; Yoon et al. 2016) has developed a recent interest in the turboelectric machine in aircraft and RPAS applications (Gerada et al. 2014; Schnell et al. 2019). Some research concentrated on high-speed machine designs for aircraft (Lahne and Gerling 2015; Yoon et al. 2016; Jikumaru and Kuwata 2018). Few methods on the integration of electric generators on the turbine gear to use it as an auxiliary power plant (Cavagnino et al. 2013; Bojoi et al. 2016). Other research focuses on a high-speed machine design study to directly integrate on the external rotor of a turbojet to use an auxiliary power (Vavilov et al. 2016). Another design used a battery-assisted turboelectric power plant to assist the takeoff phase or to use as a range extender with the series architecture aircraft integration (Becker and Sheffler 2016; Boling et al. 2020). None of the studies in the current body of knowledge have shown the impact on range and endurance when a heavy gear system and starter motor of a turboprop engine is replaced with a high-speed machine to produce a primary electrical power source. This study concentrates on developing a high-speed machine as a direct replacement of a gear system and investigates the potential weight savings of an engine configuration of this nature. A modification of the common range and endurance equation is augmented to assist in approximations of the overall effect of the proposed propulsion concept while investigating the distributed propulsion design. The study main objective is to show the impact of using a high-speed machine to pave the way for a TeDP with existing technologies, where it can be used as a replacement to the heavy gear system on a shaft powered gas turbine. Moreover, the research scope is limited to the weight comparison based on a specific model of the micro gas turbine, where comparison and savings will be changed the type of power plant used. The study drawback is that the experiment analysis is not included, which is the scope of future research.

\section{SYSTEM DESIGN}

A Pilatus PC-9 model aircraft with a scale ratio of 1:3.8 was selected for the experiment validation of the TeDP system; the details of which are provided in Table 1 and are illustrated in Fig. 1. The advantage of this model is that the suited wing area, structure and modifiable airframe can be used for future research on the multiple DEP electric motor configuration concept. In terms of the gas turbine, a Kingtech K-45P turboprop engine was chosen. Moreover, obtainability of a turbojet model (K-45) and availability of online test data provides a benchmark for performance and weight comparisons. 
Table 1. Aircraft data.

\begin{tabular}{cc}
\hline Total weight, $\mathbf{W}_{\mathbf{1}}$ & $\mathbf{1 8} \mathbf{~ k g}$ \\
\hline Wingspan, b & $2.65 \mathrm{~m}$ \\
\hline Wing Area, S & $1.117 \mathrm{~m}^{2}$ \\
\hline Area of wing, S & $0.80645 \mathrm{~m}^{2}$ \\
\hline Length of aircraft & $2.50698 \mathrm{~m}$ \\
\hline Aspect ratio, AR & 6.283 \\
\hline Oswald's efficiency factor, e & 0.758 \\
\hline Drag coefficient, $\mathrm{C}_{\text {Do }}$ & 0.0358 \\
\hline
\end{tabular}

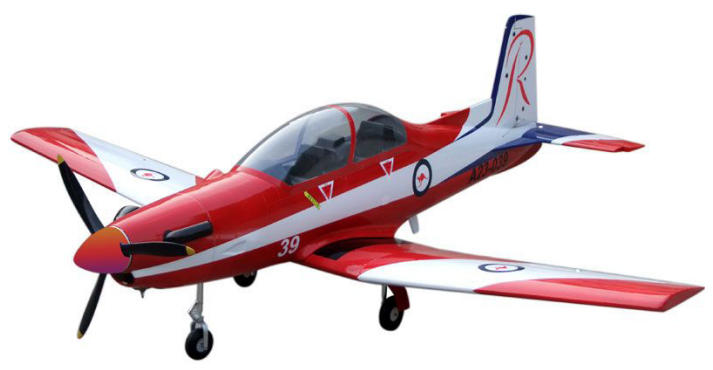

Figure 1. Pilatus PC-9 RC scale model (used with permission) (BigPlanes 2020).

The power required and the power available for the aircraft are calculated using Eqs. 1 and 2, respectively, using the equations from Fraas (1943) and Greatrix (2012).

$$
\begin{gathered}
P_{r e q}=\frac{1}{2} \mathrm{p} V^{3} \mathrm{~S} C_{D O}+\frac{W^{2}}{\frac{1}{2} p V S}\left(\frac{1}{\pi e A R}\right) \\
P_{A V}=n_{P} P_{W}
\end{gathered}
$$

where, $P_{R E Q}=$ power required, $(\mathrm{W}) ; P_{A V}=$ power available, $(\mathrm{W}) ; P_{W}=$ power. $\mathrm{W}, C_{D}=$ coefficient of drag. The results from these for the scale PC- 9 are plotted in Fig. 2.

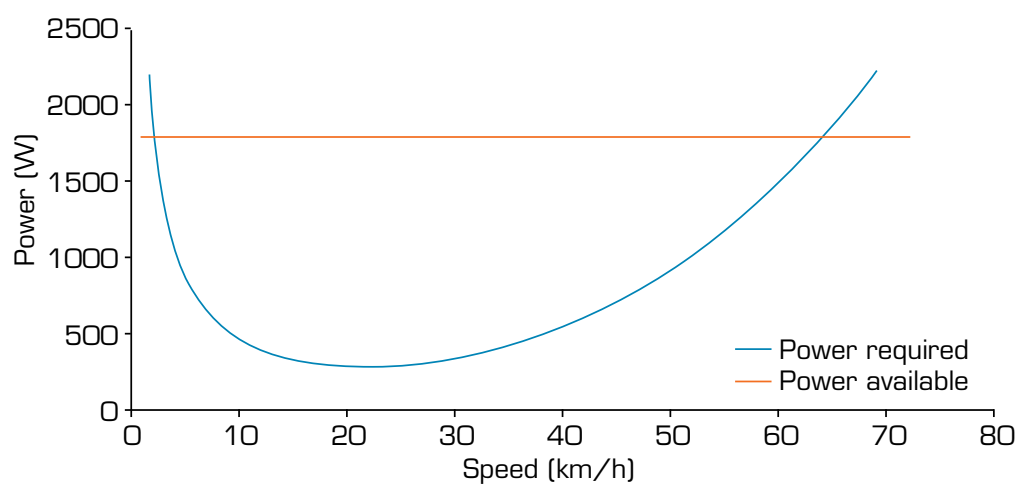

Figure 2. Aircraft data showing the power required and the power available. 
From Table 2 (Kingtech 2020), the maximum power output of the turboprop is $5.2 \mathrm{~kW}$; however, the power is set at $2 \mathrm{~kW}$ in this work. This is done to keep the aircraft within the performance parameters. Similarly, the calculations are made assuming the propulsive efficiency to be at $90 \%$. The extra power from the turboprop exhaust is not measured, which accounts for an extra $10 \%$ power from the turboprop (El-Sayed 2017). Figure 2 shows the power available for the aircraft to be $1800 \mathrm{~W}$ when the propulsive efficiency set at $90 \%$.

Table 2. Turboprop data.

\begin{tabular}{cc}
\hline Type & Free turbine \\
\hline BSFC & 0.0054 \\
\hline Max Power & $5.2 \mathrm{~kW}$ \\
\hline Max RPM & 170,000 \\
\hline Length & $335 \mathrm{~mm}$ \\
\hline
\end{tabular}

\section{SYSTEM PERFORMANCE}

Using the technique given by Anderson Jr. (2016), a modified range and endurance equations are derived, shown in Eqs. 3 and 4 , respectively, which provides a simple comparison of different hybrid configurations;

$$
\begin{gathered}
R=\frac{1}{g} \frac{3.6 n_{p}}{B S F C} \frac{C_{L}}{C_{D}} \frac{n_{E}}{a n_{E}+(1-a)} \ln \left(\frac{W_{F}+W_{A}+W_{P}}{W_{A}+W_{P}}\right), \\
E=\frac{1}{g} \frac{n_{p}}{B S F C} \frac{C_{L}^{3 / 2}}{C_{D}} \frac{n_{E}}{a n_{E}+(1-a)}(2 \rho S)^{\frac{1}{2}}\left(W_{1}^{-1 / 2}-W_{o}^{-1 / 2}\right),
\end{gathered}
$$

where,

$$
\begin{gathered}
W_{o}=W_{F}+W_{A}+W_{P} \\
W_{1}=W_{A}+W_{P}
\end{gathered}
$$

In both equations, the efficiency gain of the system to "break-even" is given by Eq. 7:

$$
e=\frac{n_{E}}{a n_{E}+(1-a)}
$$

In Eq. 7, $\mathrm{n}_{\mathrm{E}}$ is the electric efficiency, while $a$ is the hybridization factor. The hybridization factor is the ratio of power provided by the IC engine to the ratio of electric power (Eqbal et al. 2018). For a turboprop engine, the hybridization factor is one. Substituting in Eq. 7, the efficiency gain equates to one and gives the values of the direct mechanical power. Conversely, for the pure turbo-electric engine, as the hybridization factor trends to zero, the total mechanical energy trends to electric energy.

The range and endurance of the RPAS are calculated using Eqs. 3 and 4, and the data from Table 3. The weight of aircraft and engine data is taken from the manufactures specifications, while the fuel weight is $2 \mathrm{~kg}$, making the total takeoff weight $18 \mathrm{~kg}$.

Figure 3 displays the range to hybridization factor of the aircraft. Range and endurance are a direct function of electrical and propulsive efficiency. The maximum range of the pure turboprop aircraft is $71.60 \mathrm{~km}$, while the turbo-electric is $68.02 \mathrm{~km}$, which is $95 \%$ of the former. However, the propulsive efficiency of a pure electric aircraft and the aerodynamic advantages of a DEP (Ameyugo et al. 2006; Felder et al. 2011) are higher than a turboprop engine, which in turn should give a higher range and endurance. 
Table 3. Aircraft electric and weight distribution.

\begin{tabular}{cc}
\hline Electric efficiency & $95 \%$ \\
\hline Propulsive efficiency & $90 \%$ \\
\hline Aircraft weight & $14.2 \mathrm{~kg}$ \\
\hline Propulsion system weight & $1.8 \mathrm{~kg}$ \\
\hline Fuel weight & $2 \mathrm{~kg}$ \\
\hline Total weight & $18 \mathrm{~kg}$ \\
\hline $\mathrm{Cl} / \mathrm{Cd}$ at $60 \mathrm{~km} / \mathrm{h}$ & 9.93
\end{tabular}

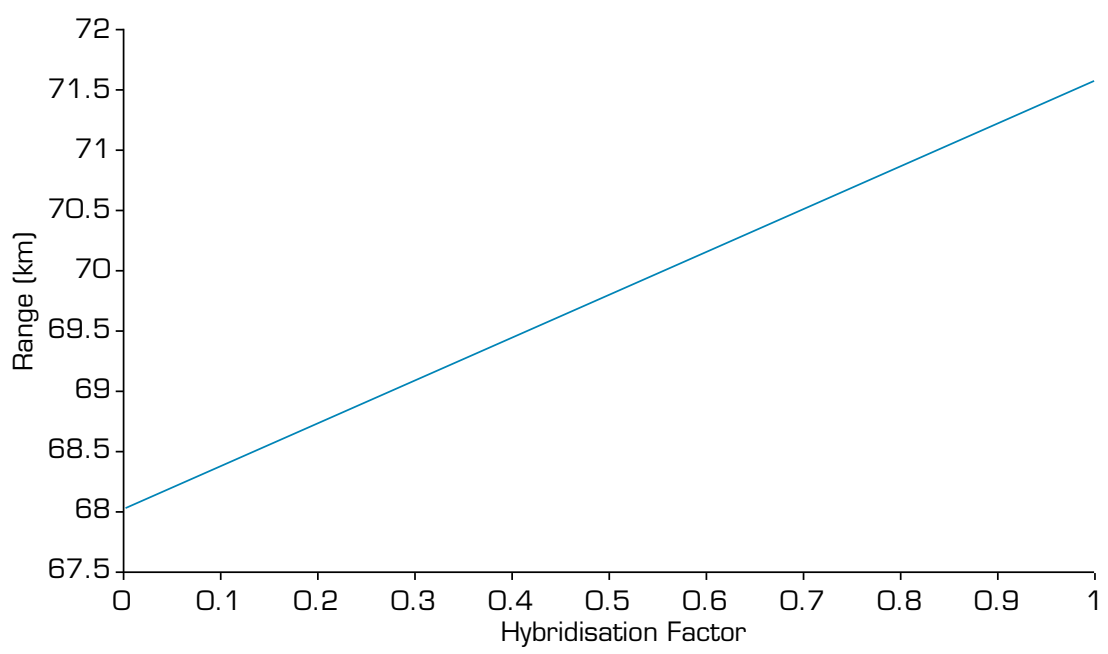

Figure 3. Range as a function hybridization factor when the velocity of aircraft is set at $60 \mathrm{~km} / \mathrm{hr}$.

\section{ELECTRIC MACHINE DESIGN}

The maximum power required for the aircraft was found to be $2 \mathrm{~kW}$ (Fig. 2). At this power output, the turboprop core operates at approximately $120 \mathrm{k}$ RPM. To achieve the speed, availability of cooling and potential to reduce weight, the permanent magnet (PM) generator option is chosen and analyzed using Ansys Maxwell (Fig. 4).

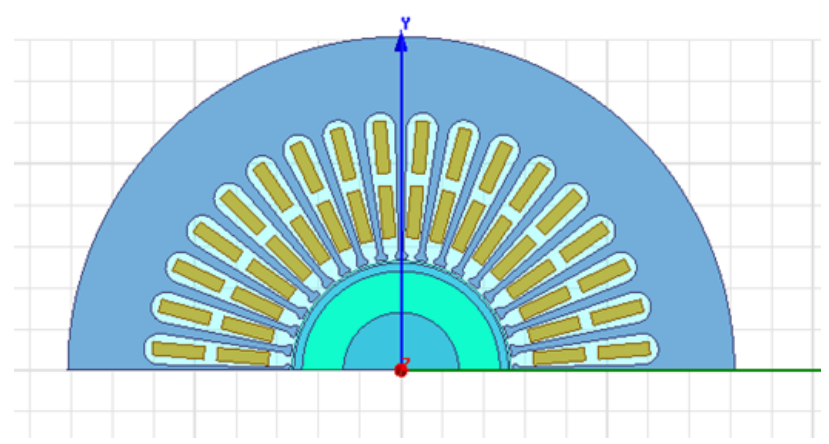

Figure 4. High speed machine in Ansys Maxwell. 
There are many types of electric machines used in power generation, which spreads from types of current, alternating current (AC) and direct current (DC), brushed and brushless, outrunner and inrunner (Krishnan 2001; Rahman et al. 2004; Bilgin et al. 2019). The machine used for the application is a brushless synchronous AC inrunner motor. Alternating current machines are lighter and more efficient than the DC machines (Fernando et al. 2016; Fernando et al. 2018). Brushless machines have higher efficiency and less maintenance than there brushed counterparts, as there are no electrical contact points. Similarly, a permanent magnetic motor is used due to the high power to weight ratio in high-speed applications. Since the outrunner creates mechanical alignment issues at high speed, an inrunner generator is designed reducing the influence of the centrifugal forces at high RPMs. The high-speed machine brushless inrunner generator requires the magnets to be aligned together under strict tolerances. A sleeved method is used for the magnetic retention, made from Inconel steel due to the capability of the tensile strength (Fernando and Gerada 2014). A high-speed ceramic bearing is used in real-life application to further increase efficiency gains, while coping better with heat dissipation in the high revolutions per minute (RPM) state. Since the high-speed machine is a high ampere AC and the electric propulsor motors are DC, a passive diode bridge rectifier is used to convert the AC to DC (Fernando et al. 2011) and a buck converter is used to change the step down the amperage. Three inrunner permanent magnet (PM) machines named machine 1, machine 2 and machine 3 (Fig. 5) have been designed and analyzed using Ansys Maxwell. The machine construction specifications, dimensions, losses and weight comparison are shown in Tables 4, 5 and 6, respectively.

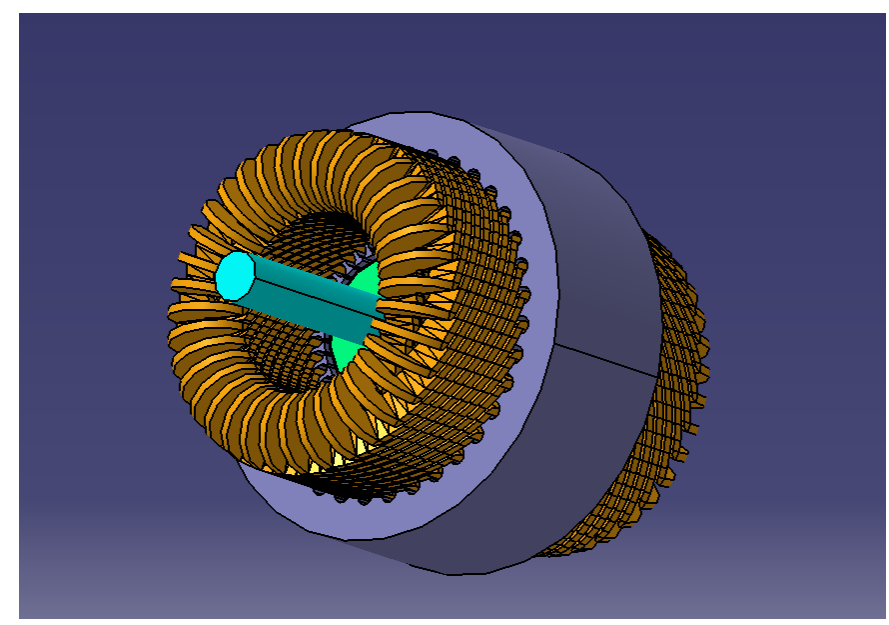

Figure 5. Design of the High RPM machine.

Table 4. Machine construction specifications.

\begin{tabular}{cc}
\hline Machine type & Surface permanent magnet machine \\
\hline Magnet retention & INCONEL alloy 718 sleeve \\
\hline Nominal frequency & $1.66 \mathrm{kHz}$ \\
\hline Core material & JFE Supercore $10 J N H F 600$ \\
\hline Number of poles & 36 \\
\hline Number of stator slots & Distributed winding \\
\hline Winding type & Passive diode bridge rectifier \\
\hline Rectification &
\end{tabular}


Table 5. Machine dimension.

\begin{tabular}{cccc}
\hline Machine & $\mathbf{1}$ & $\mathbf{2}$ & $\mathbf{3}$ \\
\hline Rotor outer diameter $(\mathrm{mm})$ & 30 & 20 & 10 \\
\hline Shaft diameter $(\mathrm{mm})$ & 8 & 6 & 4 \\
\hline Stator outer diameter $(\mathrm{mm})$ & 90 & 60 & 30 \\
\hline Stator inner diameter $(\mathrm{mm})$ & 32 & 21.5 & 10.4 \\
\hline Magnet thickness $(\mathrm{mm})$ & 10 & 7 & 5.8 \\
\hline Sleeve thickness $(\mathrm{mm})$ & 1 & 0.25 & 0.1 \\
\hline Airgap width $(\mathrm{mm})$ & 1 & 0.75 & 0.2 \\
\hline
\end{tabular}

Table 6. Machine performance at full load ( $2 \mathrm{~kW} / 120 \mathrm{k}$ RPM).

\begin{tabular}{cccc}
\hline Machine & $\mathbf{1}$ & $\mathbf{2}$ & $\mathbf{3}$ \\
\hline Core losses [W] & 14.40 & 25.91 & 51.17 \\
\hline Eddy current losses [W] & 0.65 & 161.42 & 114.14 \\
\hline Copper losses [W] & 15.01 & 11.95 & 20.69 \\
\hline Total losses [W] & 30.07 & 38.53 & 72.52 \\
\hline Efficiency [\%] $^{*}$ & 99.40 & 99.23 & 98.57 \\
\hline
\end{tabular}

*The bearing loss for the given shaft diameter is not included.

Considering the overall aircraft weight, the PM machines add a significant weight component; however, it is conceived to be far less than a gearbox generator system in which it is replacing. The different portions of the PM machine include the magnet retention sleeve, PM, winding copper and the steel core; itemized in Table 7 . The electromagnetic efficiency is in the range of 98 to 99\%; however, this does not include the bearing losses (Nelias et al. 1994; Pouly et al. 2010; Chaudhari et al. 2015). The bearing losses may involve another $3 \%$ at that speed and it can, therefore, be assumed to achieve $95 \%$ efficiency. The electromagnetic losses are mainly dissipated as heat in the machine contributed from ohmic losses in the winding, eddy current losses and core losses in the electromagnetic core. Air cooling can be used for the thermal management of the PM machines, as the heat generated is within 100 to $200 \mathrm{~W}$ range. For large high-speed machines, such as those used in turbine integrated power generation systems, an integrated active cooling system needs to be used for both the gas turbines and the electric devices and the additional weight needs to be accounted for. However, in the case of RPASs, the electrical generator is comparatively low power and can be easily air-cooled due to the external placement. Therefore, passive cooling can be used with the advantage of lower weight implications.

Table 7. Weight distribution.

\begin{tabular}{cccc}
\hline Machine & $\mathbf{1}$ & $\mathbf{2}$ & $\mathbf{3}$ \\
\hline Stator weight $[\mathrm{kg}]$ & 0.21 & 0.25 & 0.40 \\
\hline Magnet weight $[\mathrm{kg}]$ & 0.03 & 0.04 & 0.07 \\
\hline Copper weight $[\mathrm{kg}]$ & 0.15 & 0.12 & 0.19 \\
\hline Sleeve weight $[\mathrm{kg}]$ & 0.006 & 0.002 & 0.004 \\
\hline Shaft weight $[\mathrm{kg}]$ & 0.005 & 0.0051 & 0.016 \\
\hline Total weight $[\mathrm{kg}]$ & 0.41 & 0.43 & 0.70 \\
\hline Stator weight $[\mathrm{kg}]$ & 0.21 & 0.25 & 0.40 \\
\hline
\end{tabular}


Comparison of the three different versions of machines shows that the higher the diameter, the more the weight of the machine can be reduced. However, placement of the generator is directly in the path of the inlet airflow and the space envelope is constrained by the outer diameter of the machine. Considering the three different versions, the reduction of diameter from 30 to $20 \mathrm{~mm}$ increases the machine weight by approximately $18 \%$, while further lowering the diameter to $10 \mathrm{~mm}$ increases the weight by $87 \%$. Therefore, a diameter of $20 \mathrm{~mm}$ is selected considering the acceptable trade-off of weight while allowing sufficient space for inlet airflow to the engine.

\section{PROPULSION SYSTEM WEIGHT}

Figure 6(a) shows the cutaway comparison of a Kingtech k45TP similar to a standard free turbine turboprop engine used in manned aircraft. The total weight is $1800 \mathrm{~g}$, which includes the combustion core $(480 \mathrm{~g})$ and the starter motor (220 g). The starter motor is powered by a battery to rotate the compressor to a pre-set RPM and power the ignition in the combustion chamber. After ignition, the clutch mechanism disengages the starter motor and it remains as unuseful weight thereafter. Another factor to consider is the weight contribution of the free gas turbine section, which weighs $1100 \mathrm{~g}$, where the reduction gear has the highest weight share in a turboprop engine (El-Sayed 2017; Kroes and Wild 2018).

(a)

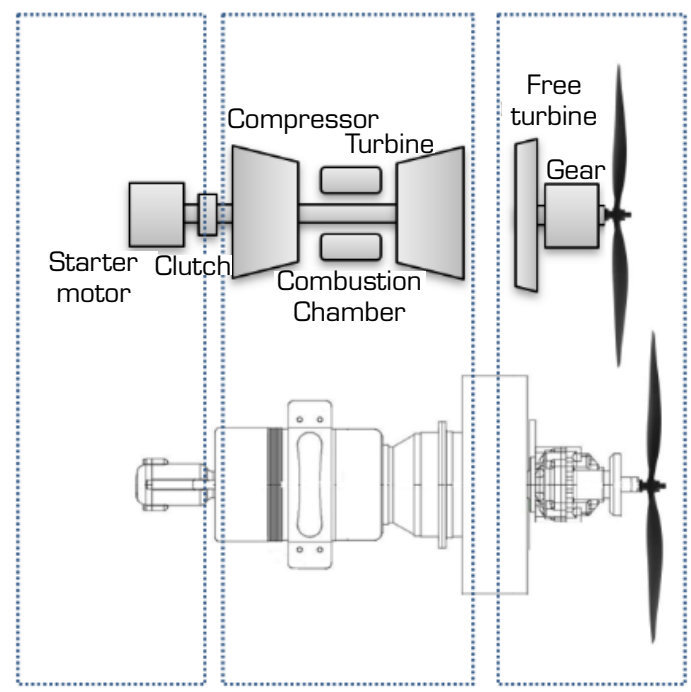

(b)

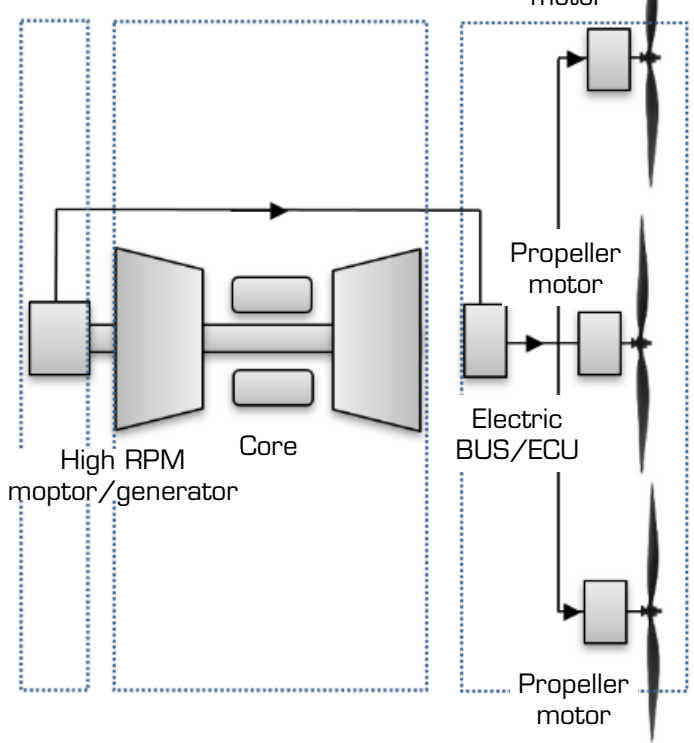

Figure 6. Comparison of parts weights.

Figure $6 \mathrm{~b}$ shows the new design replacing the starter motor and the free turbine section with a high RPM generator, shedding a total weight of $1320 \mathrm{~g}$. Since the high RPM machine is used as both a motor and a generator, it can be used as a starting device for the turbine. The existing starter motor originally on the engine is no longer required. The new addition also includes nonconductive shaft coupling part to significantly reduce heat transfer from the gas turbine shaft to the electric machine shaft. In summary, the modified design (Fig. 6b) only utilizes the turbine core from the original turboprop engine.

Machine 2 is selected for the new design, which gives a proper balance between the others.

From the Kingtech K45G data, the total weight of the gas turbine is $700 \mathrm{~g}$ and the starter motor is $220 \mathrm{~g}$. Since there is no need for the starter motor, this weight is subtracted, giving a total weight of the core to be $480 \mathrm{~g}$. After adding the weight of the high-speed machine (436g) (Table 7), the total weight of the turbine core is $916 \mathrm{~g}$ (this does not include the weight of the 
bearing and casing, which can be negligible and is equivalent to the extra anchoring mechanism and the parts removed from the turboprop).

Then, the propeller system was designed and the off-the-shelf motors were observed to provide propulsive power. After that, the weight distribution for 1, 2, 6 and 8 propulsor configurations are calculated and plotted in Fig. 7 for the $2-\mathrm{kW}$ shaft power.

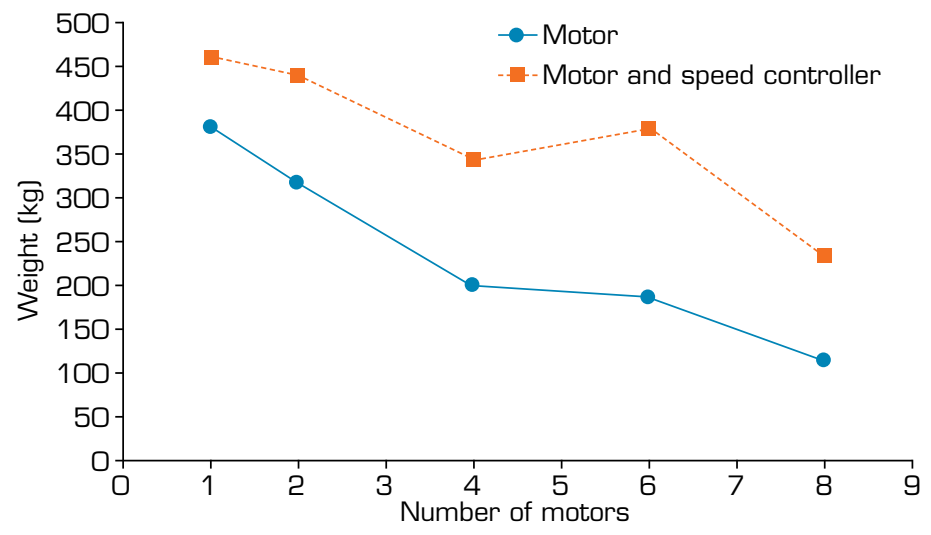

Figure 7. Weight of the motors vs. the number of motors.

Figure 7 shows that the weight of the propulsion system reduces with the number of propulsors, like previous study by Ameyugo et al. (2006). However, the weight of the motor depends on the nominal speed, application, brand and design type. The objective of this study does not focus on optimum propulsor motor/propeller selection and, however, is part of ongoing work. Also, explicitly designing the electric motor for this purpose will reduce the actual weight of the electric system and electronic speed control (ESC), as the off-the-shelf motors are designed for a drone or a single-engine aircraft, thus making the weight approximations conservative in nature. Similarly, the purpose-specific design avoids some of the electric conversion circuits used, which also contributes to further weight savings.

The eight motor configuration resulted in the lightest design and was used thereafter for a propulsor configuration. After the integration of the motors, the DEP propulsion system weight is approximately $1250 \mathrm{~g}$. The total weight includes the turbine weight (480 g), high speed machine (436.0 g) and $234.4 \mathrm{~g}$ for the ESCs and electric motors and the remaining weight of the electric bus, which is to convert the AC motor to DC power. The AC-DC power conversion circuits includes diodes, capacitors and electric wires. After the addition, the new design is $30.6 \%$ lighter than the pure turboprop.

From the addition of the new design, the updated range is calculated, keeping the electric and propulsive efficiency the same. Adding this value in Eq. 3, the new range of the aircraft is 66.6 and $70.3 \mathrm{~km}$ for 90 and $95 \%$ electric efficiencies, respectively, when comparing to the range of the pure turboprop of $71.6 \mathrm{~km}$.

Figure 8 shows the range of the new propulsion system compared to the turboprop with different efficiency parameters. As shown in previous study by Jansen et al. (2015), electrical efficiency has a vital role in the range. However, integration of the increased propulsive efficiency from a DEP can easily overcome all the range shortcomings, including structural weight gains of a DEP to increase the range further. From the base values given in Table 8, some model configurations are calculated with same range and tabulated in Table 9.

Distributed electric propulsion provides a wide range of improvements for an aircraft through increased propulsive efficiency, an increase in aerodynamic efficiency, an increase in lift and reduction in drag, a decrease in power plant weight and a decrease in aircraft structural weight (Goldschmied 1986; Ko et al. 2003; Ameyugo et al. 2006; Diedrich et al. 2006; Felder et al. 2011; Nalianda and Singh 2014; Becker and Sheffler 2016; Alba et al. 2017; Kim et al. 2018; Lian and Wu 2018; Moore and Ning 2018; Schnell et al. 2019). Even though the new turboelectric power plant is lighter than the existing pure turboprop, it may not result in improved range as it is necessary to consider the problem as a multidimensional one due to the various parameters in the range equation. A study has been performed (Table 9) using Eq. 3, keeping the current turboprop as a base aircraft reference to find 
the percentage of change in each parametric change of the new turboelectric engine given the same range as a pure turboprop. The changes in various parameters give insight into what is required to achieve equivalent base aircraft range. Arbitrary changes to propulsive efficiency, propulsion weight and other parameters give insight into the effects of the change to other parameters. Graphical representation could not be adequately achieved as it is a complicated multidimensional problem.

(a)

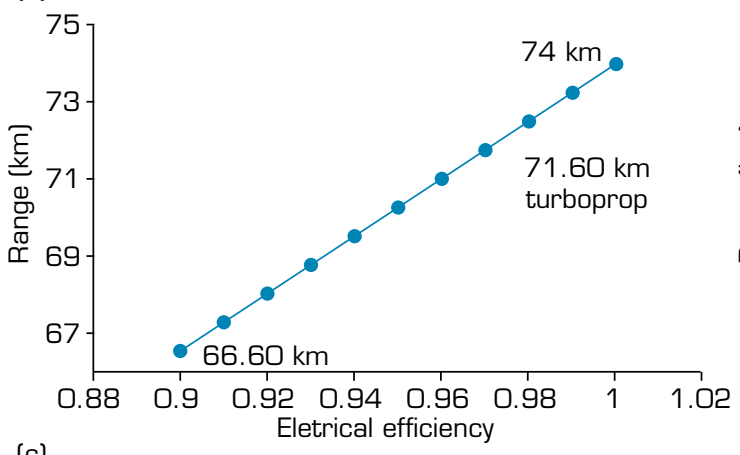

(c)

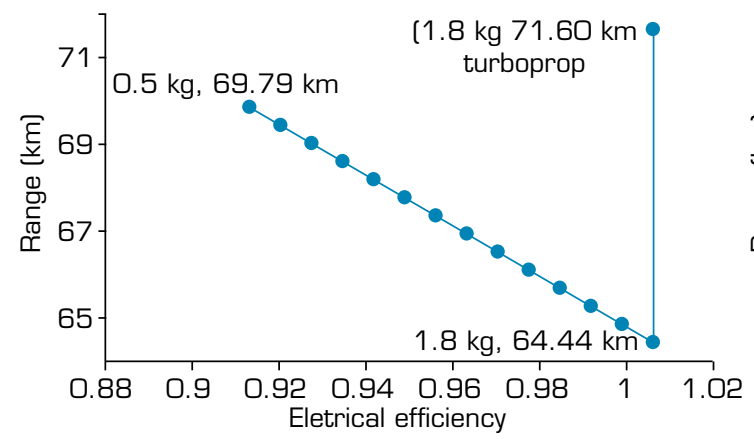

(b)

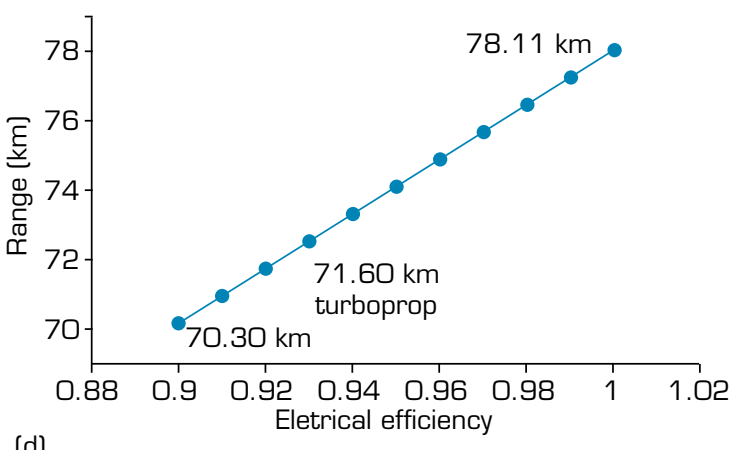

(d)

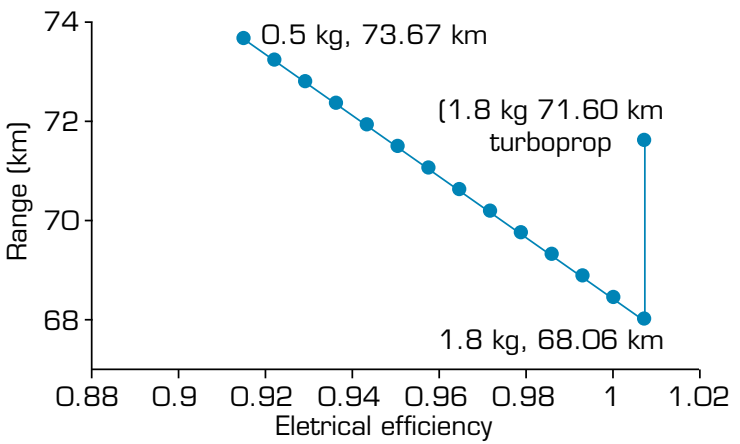

Figure 8. Range and efficiency estimation: a) range vs. electric efficiency for $90 \%$ propulsive efficiency; (b) range vs propulsive efficiency for $95 \%$ electrical efficiency; c) range vs. propulsion weight for $90 \%$ electrical efficiency and $90 \%$ propulsive efficiency. d) range vs. propulsion weight for electrical efficiency and $90 \%$ propulsive efficiency.

Table 8. New aircraft design specifications.

\begin{tabular}{cc}
\hline Aircraft & Base \\
\hline Electric efficiency & $90 \%$ \\
\hline Propulsive efficiency & $90 \%$ \\
\hline Weight of the propulsion & $1.25 \mathrm{~kg}$ \\
\hline Weigh of aircraft & $14.2 \mathrm{~kg}$ \\
\hline Weight of fuel & $2 \mathrm{~kg}$ \\
\hline Cl/CD & 9.93 \\
\hline SFC & 0.0054 \\
\hline
\end{tabular}

Table 9 gives different combinations to compare and trade off weight changes and efficiency changes to the range of the pure turboprop configuration. Column 1 shows a required increase of $7.0 \%$ in propulsive efficiency to give the comparable range to the pure turboprop. Similarly, column 13 shows a small increase in electrical efficiency and propulsive efficiency of $1.8 \%$ and a weight reduction of $0.13 \%$. With a combination of lift to drag ratio and fuel consumption, the aircraft range can approach that of the pure turboprop. From the literature (Ko et al. 2003), the multiple advantages of DEP are clearly understood. Even though the standard electric efficiency is between 
90 to $92 \%$, the propulsive efficiency of pure electrical and DEP has an advantage (Kim et al. 2018). Ameyugo et al. (2006) have shown that the DEP can reduce the weight of the aircraft wing. Similarly, the powerplant weight can be further reduced by increasing the speed of generator (Li et al. 2016; Ismagilov et al. 2018), which in turn reduces the size of the gas turbine, as well as the weight of the high-speed generator. Furthermore, construction techniques, such as the use of advanced composite materials, making hollow shafts and switching to high energy density material electric wires and shifting to composite ceramic bearings can reduce the weight further. Another option to give the same range is a reduction of specific fuel consumption (SFC), as the research from Vijlee et al. (2007) has already shown that the direct coupling of a high-speed machine can reduce fuel consumption. Taking all these into consideration, it shows the new system can have an increased range over the existing turboprop engine. The addition of the battery storage can increase the range further.

Table 9. Percentage change to achieve the same range as base aircraft.

\begin{tabular}{|c|c|c|c|c|c|c|c|c|c|c|c|c|c|}
\hline Aircraft & 1 & 2 & 3 & 4 & 5 & 6 & 7 & 8 & 9 & 10 & 11 & 12 & 13 \\
\hline Electric efficiency & - & 7.0 & 3.6 & - & - & 2.0 & 2.0 & - & - & - & - & 1.8 & 1.8 \\
\hline $\begin{array}{l}\text { Propulsive } \\
\text { efficiency }\end{array}$ & 7.0 & - & 3.6 & 3.7 & 2.7 & 2.7 & 2.0 & - & - & - & - & 0.01 & 1.8 \\
\hline $\begin{array}{l}\text { Weight of the } \\
\text { propulsion }\end{array}$ & - & - & - & -0.29 & -0.21 & - & -0.15 & - & - & - & -0.27 & - & -0.13 \\
\hline Weigh of aircraft & - & - & - & - & -2.4 & -1.8 & -1.8 & - & - & - & & - & - \\
\hline Weight of fuel & - & - & - & 3.5 & 2.6 & 1.8 & 1.8 & - & - & - & - & - & - \\
\hline $\mathrm{Cl} / \mathrm{CD}$ & - & & - & - & - & - & - & - & 7.0 & 3.5 & 3.5 & 1.8 & 1.8 \\
\hline SFC & - & & - & - & - & - & - & -7.4 & - & -3.7 & -3.7 & -1.8 & -1.8 \\
\hline
\end{tabular}

Considering the effects of DEP from various studies, the predicated range can be estimated (Table 10). It shows that the combined effects of fuel consumption, aircraft weight savings, propulsive efficiency and the drag reduction can give up to a $98.85 \%$ increase in range for the proposed design.

Table 10. New increased range after the effects of other studies combined.

\begin{tabular}{ccc}
\hline Advantage & Range $[\mathbf{k m}]$ & Change $[\%]$ \\
\hline $2.7 \%$ less fuel consumption & \\
\hline $4.4 \%$ lighter aircraft $^{1}$ & 72.25 & 2.77 \\
\hline Propulsive efficiency of $117.3 \%^{2}$ & 73.08 & 3.98 \\
\hline Drag Reduction of $28.5 \%^{3}$ & 88.66 & 10.49 \\
\hline Combination total & 98.37 & 39.92 \\
\hline
\end{tabular}

${ }^{1}$ Ko et al. (2003). 'Ameyugo et al. (2006). ${ }^{3}$ Teperin et al. (2017).

\section{GAS TURBINE CONFIGURATION VARIATIONS}

As the King Tech $\mathrm{K} 45 \mathrm{P}$ is a free-turbine engine, the free turbine section and the starter motor section were replaced with a high-speed machine. However, there are multiple gas turbine configurations that can be used for the new system. From literature, there are mostly three types of gas turbines, such as one, two and three spool configurations (Kroes and Wild 2018), which depend on the number of internal coupling shaft, linking the compressor and turbine stages together. One spool means one shaft system (compressor turbine pair), two means two shaft systems (typically on a concentric shaft). For the gas turbine, the best options are either a single spool or two-spool free turbine, as given in Fig. 9. 
(a)
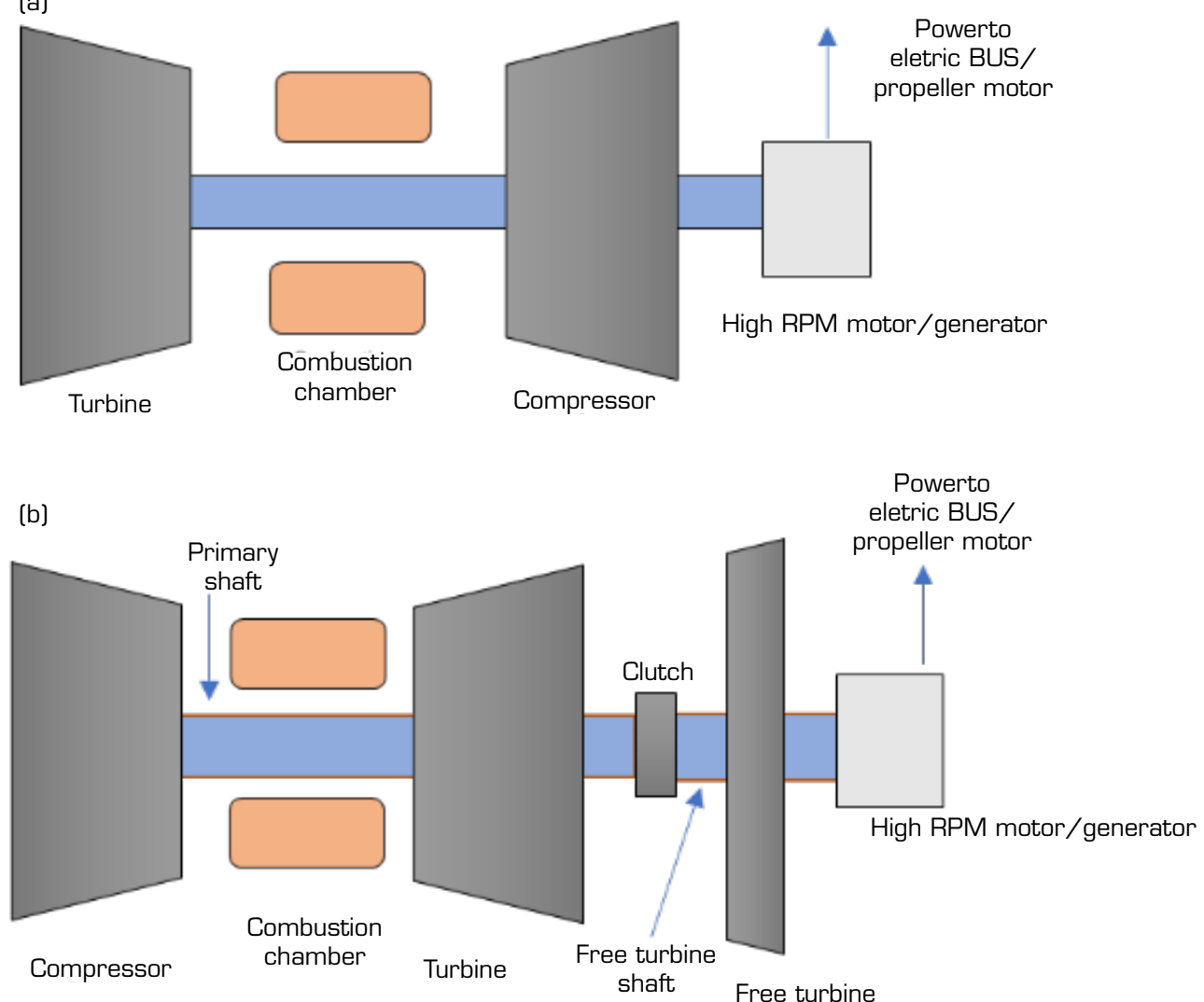

Figure 9. Comparison of single spool and double spool configuration.

Figure 9a defines the single turbine configuration where a high-speed generator replaces the starter motor. In this configuration, there is a single shaft for compressor, turbine and the electric machine. This configuration may require a redesign of the turbine to extract more power, similar to a turboshaft, or it can keep it as it is to be a partial turboelectric configuration. This configuration is often recommended for an electric generation as the power output is constant (Breeze 2016), which is similar to the case where the turbine is established to run at the optimum speed regardless of the cruising condition. Another advantage is the possibility of avoiding the clutch mechanism, a section in a gas turbine that is vulnerable to failure and also increases relative system weight. In a conventional gas turbine, the starter motor rotates the spool to a fixed speed until the combustion chamber is ignited. After that, the clutch mechanism disengages the gas starter motor. However, in this design, the high-speed machine is used as the starter motor and, after the ignition of the engine, it uses the power from the turbine to generate electricity and does not require a clutch mechanism and starter motor. Another advantage is that it is lighter than the free turbine shown in Fig. $9 \mathrm{~b}$, as there is no need for an extra turbine, shaft and bearings for the second spool (Breeze 2016).

The free turbine arrangement, Fig. $9 \mathrm{~b}$, is where the free turbine shaft is situated inside the spool shaft while running completely independently. There are many advantages of this system; since the gas turbine spool and power turbine spool are independent, they both can work at the optimum rotational condition (Jansohn 2013). Also, for constant flow and constant generator speed, the turbine can provide relatively constant power and compressor flow, regardless of the operating condition. In conclusion, in this system, the high-speed machine is used to rotate both spools in a fixed speed until the gas turbine is ignited. Thereafter, the gas turbine clutch disengages and compressor-turbine spool and the free turbine spool work as separate systems. This dual spool configuration is more complicated and heavier than the single spool system, but has a higher propulsive efficiency. In this configuration, there are multiple design possibilities, such as placing the clutch between the gas turbine and exhaust flow, but 
the clutch should either be redesigned to cope with high temperature or the shell of the gas turbine should be redesigned to shield the exhaust heat from the clutch.

The main advantage with different configurations of gas turbines are all the designs are readily used in aircraft or on the ground for electric power plants and can easily be adapted.

\section{MECHANICAL AND HEAT CONSIDERATIONS}

One of the significant concerns while using a high-speed motor is heat generation, which is vital in the case of a large scale (potentially manned) aircraft where latent heat can be a design problem. For this $2-\mathrm{kW}$ system heat generation is minimal. Table 6 showed that the heat generated from the electric machine is under $50 \mathrm{~W}$, allowing air cooling methods to create the required heat dissipation. This avoids the need for complex heat sink systems for the electric machine, as well as the circuitry. However, in the case of large aircrafts, a system like jacket cooling (Canders et al. 2019) and regenerative cooling (Pizzarelli 2017) may be required. Nevertheless, in larger aircrafts, electrical efficiency is a significant concern, as discussed by Kim et al. (2018).

The primary concern is placing the electrical systems, including the generator, in unheated flow for maximum heat transfer and cooling. This, of course, could be challenging, as the generator must be at close proximity to the turbine to access the appropriate shaft. Heat transfer through the turbine shaft to the generator may also provide means to overheat the generator. Pre-existing insulation materials can overcome this, such as paints in coupling and different shaft materials directly reduce heat transfer. Vented flow using channels could be effective in heat dissipation at the cost of drag.

The high-speed machine is favorable from a mechanical perspective. For a gas turbine, there is frequent maintenance of the required gear system where the majority of maintenance and repair effort is relatively larger when compared to other subsystems (Samaranayake 2006; Ward et al. 2010; Mrzljak et al. 2019). Modern electric machines require less maintenance due to the reduction of moving parts and mechanical contact points (Ploetner et al. 2013; Sarlioglu and Morris 2015) with the high-speed machines a well-developed concept and readily available in the market (Moghaddam 2014; Zhang et al. 2016). The main consideration of the system is the required cooling. If sufficient cooling is not maintained in operation, the machine efficiency is reduced (Yang et al. 2016; Canders et al. 2019). The integration loss is another matter of concern. If the machine is not integrated appropriately, there will be mechanical coupling loss, which ends in a total power loss.

\section{CONCLUSION}

Replacing the gearing of the gas turbine with a high-speed machine and distributing the power through a DEP results in a propulsion system that is $30.6 \%$ lighter than the existing gas turbine, which is less than reported in the existing studies, where the hybrid system is larger than the existing pure engine. After considering the advantages of DEP on propulsive efficiency, fuel saving, aircraft weight and drag reductions of the new design could give an increased range of $98.5 \%$. The weight can be reduced further by increasing the speed to provide more rotational energy for electrical generation. The primary concern of the new system is the electric efficiency, where there is a trade-off between minimization of resistance and addition weight due to wires and associated electronics. Apart from the advantages of electrical distribution, existing studies show advantages of increased propulsive efficiency, reduced aircraft weight and fuel-savings by using a directly coupled high speed engine. These can increase the range and endurance of the RPAS. The derived equations give a simplified formula that can be used to calculate the range and endurance, which is an excellent tool to optimize the new design. Since the equation gives the break-even through the hybridization factor, it can be called a universal equation that can be used in parallel, series and series-parallel hybrid configuration.

Modification of the new equation to include a battery system could be beneficial. Maximum electric power is required for takeoff and the propulsion system here is designed to cope with this requirement. This excess energy produced during cruise could 
be stored in a battery system and can be used as a range extender. Optimizing the propulsion system for the cruise and using the extra battery power for takeoff can be another option.

One of the critical problems is that the off-the-shelf outrunner motors were used as the propulsors, which involved intricate electric designs to convert from AC to DC and conversion of electric powers from the high-speed machine to small motors. These add extra weight and it was not possible to find an adequate range of motors which are suitable for the DEP. Designing a propulsor motor and the speed controllers that are specific to this high-speed design can overcome all these power conversions and mass issues. An optimized system that balances the electric and propulsor system is of future interest.

All the design considerations open up a new area of investigation, but the principal objective of this study is to show the advantage of the high-speed machine and its advantage on the propulsion weight savings.

\section{AUTHORS' CONTRIBUTION}

Conceptualization: Eqbal M and Wild G; Methodology: M Eqbal, N Fernando, M Marino and G Wild; Investigation: M Eqbal, N Fernando, M Marino and G Wild; Writing - Original Draft: M Eqbal; Writing - Review and Editing: Fernando N, M Marino and G Wild; Funding Acquisition: Wild G and Marino M; Resources: Eqbal M, Fernando N, M Marino and G Wild; Supervision: N Fernando, M Marino and G Wild.

\section{DATA AVAILABILITY STATEMENT}

All dataset were generated or analyzed in the current study.

\section{FUNDING}

Not applicable.

\section{ACKNOWLEDGEMENTS}

Not applicable.

\section{REFERENCES}

Alba C, Elham A, German B, Veldhuis LL (2017) A Surrogate-Based Multi-Disciplinary Design Optimization Framework Exploiting Wing-Propeller Interaction. Paper presented 18th AIAA/ISSMO Multidisciplinary Analysis and Optimization Conference. AIAA; Denver, Colorado, United States. https://doi.org/10.2514/6.2017-4329

Ameyugo G, Taylor M, Singh R (2006) Distributed Propulsion Feasibility Studies. Paper presented 25th International Congress of the Aeronautical Sciences. ICAS; Hamburg, Germany.

Anderson Jr. JD (2016) Introduction to Flight. New York: McGraw-Hill Higher Education. 
Armstrong M (2015) Superconducting Turboelectric Distributed Aircraft Propulsion. Paper presented Cryogenic Engineering Conference / International Cryogenic Materials Conference 2015. CEC/ICMC; Tucson, Arizona, United States.

Becker M, Sheffler D (2016) Designing a high speed, stealthy, and payload-focused VTOL UAV. Paper presentedc 2016 IEEE Systems and Information Engineering Design Symposium (SIEDS). IEEE; Charlottesville, Virginia, United States. https://doi. org/10.1109/SIEDS.2016.7489294

BigPlanes (2020) Pilatus PC-9 Red. [accessed Feb 22 2020] https://www.bigplanes.nl/contents/en-uk/p805_PC9-ESM-rcscale-model-airplane-arf-warbird-vliegtuig-plane.html

Bilgin B, Liang J, Terzic MV, Dong J, Rodriguez R, Trickett E, Emadi A (2019) Modeling and Analysis of Electric Motors: State-of-the-Art Review. IEEE Trans Transp Electrification 5(3):602-617. https://doi.org/10.1109/TTE.2019.2931123

Bojoi R, Cavagnino A, Tenconi A, Vaschetto S (2016) Control of Shaft-Line-Embedded Multiphase Starter/Generator for Aero-Engine. IEEE Trans Ind Electron 63(1):641-652. https://doi.org/10.1109/TIE.2015.2472637

Boling JS, Zha G, Zeune C (2020) A High-Speed, High-Efficiency VTOL Concept Using CoFlow Jet Airfoil. AIAA Aviation 2020 Forum. AIAA; Virtual Event. https://doi.org/10.2514/6.2020-2792.c1

Borer NK, Cox DE, Wallace RD (2019) Flight Performance Maneuver Planning for NASA's X-57 "Maxwell” Flight Demonstrator-Part 1: Power-Off Glides. Paper presented AIAA Aviation 2019 Forum. AIAA; Dallas, Texas, United States. https://doi.org/10.2514/6.2019-2855

Bowman CL, Marien TV, Felder JL (2018) Turbo- and Hybrid-Electrified Aircraft Propulsion for Commercial Transport. Paper presented 2018 AIAA/IEEE Electric Aircraft Technologies Symposium. IEEE; Cincinnati, Ohio, United States. https:// doi.org/10.2514/6.2018-4984

Breeze P (2016) Gas-turbine power generation. Cambrige: Academic Press. https://doi.org/10.1016/B978-0-12-804005-8.00004-5

Canders W-R, Hoffmann J, Henke M (2019) Cooling Technologies for High Power Density Electrical Machines for Aviation Applications. Energies 12(23):4579. https://doi.org/10.3390/en12234579

Cavagnino A, Li Z,Tenconi A,Vaschetto S (2013) Integrated Generator for More Electric Engine: Design and Testing of a Scaled-Size Prototype. IEEE Trans Ind Appl 49(5):2034-2043. https://doi.org/10.1109/TIA.2013.2259785

Chaudhari CP, Thakare BB, Patil SR, Gunjal SU (2015) A Study Of Bearing And Its Types. Int J Adv Sci 4(Special Issue 1):1674-1681.

Diedrich A, Hileman J, Tan D, Willcox K, Spakovszky Z (2006) Multidisciplinary Design and Optimization of the Silent Aircraft. Paper presented 44th AIAA Aerospace Sciences Meeting and Exhibit. AIAA; Reno, Nevada, United States. https:// doi.org/10.2514/6.2006-1323

El-Sayed AF (2017) Aircraft Propulsion and Gas Turbine Engines. New York: CRC Press.

Eqbal MAS, Fernando W, Marino M, Wild G (2018) Hybrid propulsion systems for remotely piloted aircraft systems. Aerospace 5(2):34. https://doi.org/10.3390/aerospace5020034

Felder JL, Brown VG, DaeKim H, Chu J (2011) Turboelectric distributed propulsion in a hybrid wing body aircraft. Paper presented XX International Symposium on Air Breathing Engines 2011 (ISABE 2011). ISABE; Gothenburg, Sweden.

Fernando WUN (2014) Control of switched reluctance generators in continuous conduction mode. 2014 IEEE Energy Conversion Congress and Exposition (ECCE). IEEE; Pittsburg, Pensilvania, United States. https://doi.org/10.1109/ ECCE.2014.6953576 
Fernando WUN, Barnes M (2013) Electromagnetic Energy Conversion Efficiency Enhancement of Switched Reluctance Motors With Zero-Voltage Loop Current Commutation. IEEE Trans Energy Convers 28(3):482-492. https://doi.org/10.1109/ TEC.2013.2272638

Fernando WUN, Gerada C (2014) High speed permanent magnet machine design with minimized stack-length under electromagnetic and mechanical constraints. Int J Appl Electromagn Mech 46(1):95-109.

Fernando WUN, Barnes M, Marjanovic O (2011) Direct drive permanent magnet generator fed AC-DC active rectification and control for more-electric aircraft engines. IET electric power applications 5(1):14-27. https://doi.org/10.1049/ietepa.2009.0280

Fernando N, Vakil G, Arumugam P, Amankwah E, Gerada C, Bozhko S (2016) Impact of Soft Magnetic Material on Design of High-Speed Permanent-Magnet Machines. IEEE Trans Ind Electron 64(3):2415-2423. https://doi.org/10.1109/ TIE.2016.2587815

Fernando N, Arumugam P, Gerada C (2018) Design of a stator for a high-speed turbo-generator with fixed permanent magnet rotor radius and volt-ampere constraints. IEEE Trans Energy Convers 33(3):1311-1320. https://doi.org/10.1109/ TEC.2018.2804955

Fraas AP (1943) Aircraft Power Plants. Mcgraw. New York: McGraw-Hill.

Gerada D, Mebarki A, Brown NL, Gerada C, Cavagnino A, Boglietti A (2014) High-Speed Electrical Machines: Technologies, Trends, and Developments. IEEE Trans. Ind. Electron 61(6):2946-2959. https://doi.org/10.1109/TIE.2013.2286777

Goldschmied F (1986) Aerodynamic Design of Low-Speed Aircraft with a NASA Fuselage/Wake-Propeller Configuration. Aircraft Systems, Design and Technology Meeting. AIAA; Dayton, Ohio, United States. https://doi.org/10.2514/6.1986-2693

Greatrix DR (2012) Powered Flight. New York: Springer. https://doi.org/10.1007/978-1-4471-2485-6

Hanson DB, Fink MR (1979) The importance of quadrupole sources in prediction of transonic tip speed propeller noise. J Sound Vib 62(1):19-38. https://doi.org/10.1016/0022-460X(79)90554-6

Hayes JG, Goodarzi GA (2018) Electric Powertrain: Energy Systems, Power Electronics and Drives for Hybrid, Electric and Fuel Cell Vehicles. Hoboken: John Wiley \& Sons Ltd. https://doi.org/10.1002/9781119063681

Hill G, Brown S, Geiselhart K, Burg C (2004) Integration of Propulsion-Airframe-Aeroacoustic Technologies and Design Concepts for a Quiet Blended-Wing-Body Transport. Paper presented AIAA 4th Aviation Technology, Integration and Operations (ATIO) Forum. AIAA; Chicago, Illinois, United States. https://doi.org/10.2514/6.2004-6403

Hitchens FE (2015) Propeller Aerodynamics: The History, Aerodynamics \& Operation of Aircraft Propellers. Salmiya: AUK Academic.

Ismagilov FR, Vavilov VY, Ayguzina VV (2018) Basics of High-Speed Electrical Machines. In El-Shahat, editor. Electric Machines for Smart Grids Applications: Design, Simulation and Control. Österriech : BoD - Books on Demand.

Jansen R, Brown GV, Felder JL, Duffy KP (2015) Turboelectric Aircraft Drive Key Performance Parameters and Functional Requirements. Paper presented 51st AIAA/SAE/ASEE Joint Propulsion Conference. AIAA; Orlando, Florida, United States. https://doi.org/10.2514/6.2015-3890

Jansohn P (2013) Modern Gas Turbine Systems: High Efficiency, Low Emission, Fuel Flexible Power Generation. Sawston: Woodhead Publishing. https://doi.org/10.1533/9780857096067

Kim HD, Perry AT, Ansell PJ (2018) A Review of Distributed Electric Propulsion Concepts for Air Vehicle Technology. 2018 AIAA/ IEEE Electric Aircraft Technologies Symposium. IEEE; Cincinnat, Ohio, United States. https://doi.org/10.2514/6.2018-4998 
Kingtech Turbines (2020) Kingtech K45 TP. [accessed Jan 10 2020] http://www.kingtechturbines.com/products/index. php?main_page=product_info\&cPath=1\&products_id=53

Ko A, Schetz J, Mason WH (2003) Assessment of the Potential Advantages of Distributed-Propulsion for Aircraft. Paper presented 16th International Symposium on Air Breathing Engines (ISABE). Cleveland, Ohio, United States.

Krishnan R (2001) Electric Motor Drives: Modeling, Analysis, and Control. London: Pearson Education.

Kroes M, Wild T (2018) Aircraft Powerplants. New York: McGraw-Hill.

Lahne H-C, Gerling D (2015) Comparison of state-of-the-art high-speed high-power machines: Research study including a design example of a $50000 \mathrm{rpm}$ induction machine. Paper presented IECON 2015 - 41st Annual Conference of the IEEE Industrial Electronics Society. IEEE; Yokohama, Japan. https://doi.org/10.1109/IECON.2015.7392646

Li S, Li Y, Choi W, Sarlioglu B (2016) High-Speed Electric Machines: Challenges and Design Considerations. IEEE Trans Transp Electrification 2(1):2-13. https://doi.org/10.1109/TTE.2016.2523879

Lian Z, Wu J (2018) Aerodynamics and Propulsive Efficiency of a Blended-Wing-Body Aircraft with Distributed Propulsion System During Takeoff. Int J Aeronaut Space Sci 19(4):799-804. https://doi.org/10.1007/s42405-018-0066-7

Ma X, Su R, Tseng KJ, Wang S, Zhang X, Vaiyapuri V, Chandana G, Amit G, Sivakumar N (2015) Review of high speed electrical machines in gas turbine electrical power generation. Paper presented TENCON 2015 - 2015 IEEE Region 10 Conference. IEEE; Macao, China. https://doi.org/10.1109/TENCON.2015.7372765

Moghaddam RR (2014) High speed operation of electrical machines, a review on technology, benefits and challenges. Paper presented 2014 IEEE Energy Conversion Congress and Exposition (ECCE). IEEE; Pittsburg, Pensilvania, United States. https://doi.org/10.1109/ECCE.2014.6954160

Moore MD, Fredericks B (2014) Misconceptions of Electric Aircraft and their Emerging Aviation Markets. Paper presented 52nd Aerospace Sciences Meeting. AIAA; Maryland, Maryland, United States. https://doi.org/10.2514/6.2014-0535

Moore KR, Ning A (2018) Distributed Electric Propulsion Effects on Existing Aircraft Through Multidisciplinary Optimization. Paper presented 2018 AIAA/ASCE/AHS/ASC Structures, Structural Dynamics, and Materials Conference. AIAA; Kissimmee, Florida, United States. https://doi.org/10.2514/6.2018-1652.c1

Mrzljak V, Anđelić N, Lorencin I, Car Z (2019) Analysis of Gas Turbine Operation before and after Major Maintenance. Journal of Maritime and Transportation Sciences 57:57-70.

Nalianda D, Singh R (2014) Turbo-electric distributed propulsion - opportunities, benefits and challenges. Aircr Eng Aerosp Technol 86(6):543-549. https://doi.org/10.1108/AEAT-03-2014-0035

Nasr A, Hlioui S, Gabsi M, Mairie M, Lalevee D (2017) Experimental investigation of a Doubly-Excited Flux-Switching Machine for aircraft DC power generation. Paper presented 2017 IEEE International Electric Machines and Drives Conference (IEMDC). IEEE; Miami, Florida, United States. https://doi.org/10.1109/IEMDC.2017.8002113

Nelias D, Seabra J, Flamand L, Dalmaz G (1994) Power Loss Prediction in High-Speed Roller Bearings. Tribol Int 27:465-478. https://doi.org/10.1016/S0167-8922(08)70332-8

Pizzarelli M (2017) Regenerative cooling of liquid rocket engine thrust chambers. Roma: Agenzia Spaziale Italiana.

Ploetner KO, Schmidt M, Baranowski D, Isikveren AT, Hornung M (2013) Operating Cost Estimation for Electric-Powered Transport Aircraft. Paper presented 2013 Aviation Technology, Integration, and Operations Conference. AIAA; Los Angeles, California, United States. https://doi.org/10.2514/6.2013-4281 
Pouly F, Changenet C, Ville F, VelexmP, Damiens B (2010) Investigations on the power losses and thermal behaviour of rolling element bearings. Proc. IMechE Vol. 224 Part J: J. Engineering Tribology 224(9):925-933. https://doi. org/10.1243/13506501JET695

Pyrhonen J, Nerg J, Kurronen P, Lauber U (2009) High-speed high-output solid-rotor induction-motor technology for gas compression. IEEE Trans. Ind. Electron 57(1):272-280. https://doi.org/10.1109/TIE.2009.2021595

Rahman MA, Chiba A, Fukao T (2004) Super high speed electrical machines - summary. Paper presented IEEE Power Engineering Society General Meeting, 2004. IEEE; Dever, Colorado, United States. https://doi.org/10.1109/PES.2004.1373062

Rao AA, Sharma A, van Dijk R (2017) A CFD Based Parametric Analysis of S-Shaped Inlet for a Novel Blended Wing Body Aircraft. Paper presented International Conference on Advances in Thermal Systems, Materials and Design Engineering (ATSMDE2017).

Samaranayake P (2006) Current practices and problem areas in aircraft maintenance planning and scheduling-interfaced/ integrated system perspective. Paper presented Proceedings Of The 7th Asia Pacific Industrial Engineering And Management Systems Conference 2006. Bangkok, Thailand.

Sarlioglu B, Morris CT (2015) More Electric Aircraft: Review, Challenges, and Opportunities for Commercial Transport Aircraft. IEEE Trans Transp Electrification 1(1):54-64. https://doi.org/10.1109/TTE.2015.2426499

Schnell R, Zhao X, Rallis E, Kavvalos M, Sahoo S, Schnoes M, Kyprianidis K (2019) Assessment of a Turbo-Electric Aircraft Configuration with Aft-Propulsion Using Boundary Layer Ingestion. Aerospace 6(12):134. https://doi.org/10.3390/ aerospace6120134

Selema AS, Osheba DS, El-Shanawany MM, Tahoun SM (2018) Design and Analysis of a Brushless Three Phase Flux Switching Generator for Aircraft Auxiliary Power Unit. Paper presented 2018 Twentieth International Middle East Power Systems Conference (MEPCON). IEEE; Cairo, Egypt. https://doi.org/10.1109/MEPCON.2018.8635288

Smith Junior LH (1993) Wake ingestion propulsion benefit. J Propuls Power 9(1):74-82. https://doi.org/10.2514/3.11487

Song Z, Liu, Zhao H (2019) Comparative Analysis of Slotless and Coreless Permanent Magnet Synchronous Machines for Electric Aircraft Propulsion. Paper presented 2019 22nd International Conference on Electrical Machines and Systems (ICEMS). IEEE; Harbin, China. https://doi.org/10.1109/ICEMS.2019.8921494

Jikumaru T, Kuwata G (2018) 1.2kW 100,000rpm high speed motor for aircraft. Paper presented 2018 International Power Electronics Conference (IPEC-Niigata 2018 -ECCE Asia). IEEE; Niigata, Japan.

Teperin L, El-Salamony M, Moharam A, Shehata M (2017) Investigation on Boundary Layer Ingestion Propulsion for UAVs. Paper presented International Micro Air Vehicle Conference and Flight Competition (IMAV). IMAV; Toulouse, France. [accessed Mar 05 2020] http://www.imavs.org/papers/2017/307_imav2017_proceedings.pdf

Thomas RH (2003) Aeroacoustics of Propulsion Airframe Integration: Overview of NASA's Research. Paper presented NOISE-CON 2003. Cleveland, Ohio, United States. [accessed Jan 05 2020] https://www.cs.odu.edu/ mln/ltrs-pdfs/NASA2003-noisecon-rht.pdf

Varyukhin AN, Ismagilov FR, Vavilov VY, Papini L, Ayguzina VV, Gordin MV (2019) Design of 150-kVA 24,000-rpm High-Speed Permanent-Magnet Generator for More Electric Aircrafts. Paper presented 2019 International Conference on Electrotechnical Complexes and Systems (ICOECS). IEEE; Ufa, Russia. https://doi.org/10.1109/ICOECS46375.2019.8949918

Vavilov V, Ismagilov F, Khayrullin I, Karimov R (2016) Multi-Disciplinary Design of High-RPM Electric Generator with External Rotor for Unmanned Aerial Vehicle. Int Rev Aerosp Eng 9(4):123-130. https://doi.org/10.15866/irease.v9i4.10340 
Vijlee SZ, Ouroua A, Domaschk LN, Beno JH (2007) Directly-Coupled Gas Turbine Permanent Magnet Generator Sets for Prime Power Generation On Board Electric Ships. Paper presented 2007 IEEE Electric Ship Technologies Symposium. IEEE; Arlington, Texas, United States. https://doi.org/10.1109/ESTS.2007.372108

Wang X, Zhou S, Wu L, Zhao M, Hu C (2019) Iron Loss and Thermal Analysis of High Speed PM motor Using Soft Magnetic Composite Material. Paper presented 2019 22nd International Conference on Electrical Machines and Systems (ICEMS). IEEE; Harbin, China. https://doi.org/10.1109/ICEMS.2019.8922504

Ward M, McDonald N, Morrison R, Gaynor D, T. Nugent (2010) A performance improvement case study in aircraft maintenance and its implications for hazard identification. Ergonomics 53(2): 247-267. https://doi.org/10.1080/00140130903194138

Xu L, Wang H, Xiong H, Ke Z, Woo J, Zhang J, Dong S (2019). Design and Experimental Evaluation of a High Specific Power Permanent Magnet Synchronous Machine. Paper presented 2019 IEEE International Electric Machines \& Drives Conference (IEMDC). IEEE; San Diego, California, United States. https://doi.org/10.1109/IEMDC.2019.8785246

Yang Y, Bilgin B, Kasprzak M, Nalakath S, Sadek H, Preindl M, Cotton J, Schofield N, Emadi A (2016) Thermal Management of Electric Machines. IET Electr Syst Transp 7(2):104-116. https://doi.org/10.1049/iet-est.2015.0050

Yoon A, Xuan Y, Martin J, Yuanshan C, Haran K (2016) A high-speed, high-frequency, air-core PM machine for aircraft application. Paper presented 2016 IEEE Power and Energy Conference at Illinois (PECI). IEEE; Urbana, Illinois, United States. https://doi.org/10.1109/PECI.2016.7459221

Yu L, Zhang Z, Gerada D, Gerada G (2018) Performance comparison of doubly salient reluctance generators for high-voltage DC power system of more electric aircraft. Paper presented 2018 IEEE International Conference on Electrical Systems for Aircraft, Railway, Ship Propulsion and Road Vehicles \& International Transportation Electrification Conference (ESARSITEC). IEEE; Nottnghan, United Kingdom. https://doi.org/10.1109/ESARS-ITEC.2018.8607694

Zhang F, Du G, Wang T, Liu G (2016) Review on Development and Design of High Speed Machines. Transactions of China Electrotechnical Society 31(7):1-18. 